\title{
Gambaran Tingkat Kecemasan Anak UsiaPrasekolah Yang MengalamiHospitalisasi : Literature Review
}

\author{
Hibatul Aliyah ${ }^{1 *}$, Aida Rusmariana ${ }^{2}$ \\ ${ }^{1,2}$ Program Studi Sarjana Keperawatan, Universitas Muhammadiyah Pekajangan Pekalongan, \\ Indonesia \\ *email:admin@umpp.id
}

\begin{abstract}
During preschool age, the increasing intensity of children's physical activities may make them feel tired easily. In this period, their immune system has not stable yet. Those conditions make children more susceptible to various diseases and often cause them hospitalized. For some children, hospitalization can bring about strange feeling and anxiety.Topurpose of this study was to describe the level of anxiety in preschool children who experience hospitalization. This study was a secondary research in the form of literature review. Five articles were taken and chosen from Scilit, Garba Garuda and Google Scholar based on the determined inclusion criteria. The results of the literature review analysis showed that $32.6 \%$ preschool children who were hospitalized experienced 'moderate' level of anxiety, $27.5 \%$ experienced 'mild' anxiety, $23.9 \%$ felt 'severe' level of anxiety, and $16.0 \%$ of children felt 'panicked'. Most of preschool children who were hospitalized experienced moderate level of anxiety. Therefore, nurses in children's wards are expected to provide nursing care,pay attention to their psychological development, and let them play to reduce their anxiety levels.
\end{abstract}

Keywords: Preschool age children; fas; hospitalization; anxiety level

\begin{abstract}
Abstrak
Pada usia prasekolah, aktifitas fisik pada anak meningkat yang menyebabkan anak sering kelelahan dan menyebabkan rentang terserang penyakit akibat system imun belum stabil atau daya tahan tubuh lemah sehingga mengharuskan anak untuk menjalani hospitalisasi. Bagi anak memasuki rumah sakit adalah seperti memasuki dunia asing, sehingga akibatnya adalah kecemasan. Mengetahui gambaran tingkat kecemasan pada anak usia prasekolah yang mengalami hospitalisasi menggunakan studi literature review. Penelitian ini merupakan penelitian sekunder berjenis literature review. Metode yang digunakan dalam pemilihan artikel yaitu dengan melakukan penelusuran literature dari sumber database Scilit, Garba Garuda dan Google Scholar didapatkan 5 artikel yang sesuai dengan criteria inklusi penelitian. Hasil analisis literature review menunjukkan bahwa anak usia prasekolah yang mengalami hospitalisasi mengalami tingkat kecemasan sedang memiliki hasil terbanyak yaitu sebanyak 45 anak $(32,6 \%)$, kecemasan ringan sebanyak 38 anak $(27,5 \%)$, kecemasan berat sebanyak 33 anak (23,9\%), dan panic sebanyak 22 anak (16,0 \%). Anak usia prasekolah yang mengalami hospitalisasi paling banyak mengalami tingkat kecemasan sedang. Diharapkan perawat di ruang anak dapat memberi asuhan keperawatan dengan tetap memperhatikan aspek psikologi dan tumbuh kembang anak serta memberikan kebutuhan bermain bagi anak saat dirawat untuk menurunkan tingkat kecemasan pada anak.
\end{abstract}

Kata kunci: Anak usia prasekolah; fas; hospitalisasi; tingkat kecemasan

\section{Pendahuluan}

Anak usia prasekolah merupakan anak yang berusia 3- 6 tahun. Usia 3-6 tahun ini biasa disebut The Wonder Years yaitu masa dimana seorang anak memiliki rasa keingintahuan yang tinggi terhadap sesuatu [1]. Pada usia ini, aktifitas fisik pada anak meningkat yang menyebabkan anak sering kelelahan dan menyebabkan rentan terserang penyakit akibat sistem imun belum stabil atau daya tahan tubuh lemah 


\section{Prosiding Seminar Nasional Kesehatan Lembaga Penelitian dan Pengabdian Masyarakat Universitas Muhammadiyah Pekajangan Pekalongan}

sehingga mengharuskan anak untuk menjalani hospitalisasi [2]. Jika anak sakit, orang tua terkadang bimbang ataupun tidak bisa memberi perawatan optimal di rumah. Kondisi semacam itu yang memforsir anak wajib memperoleh perawatan intensif di rumah sakit[3]. Prevalensi anak yang sakit dan di rawat dirumah sakit berdasarkan data World Health Organization (WHO) tahun 2018 bahwa 3\% - 10\% penderita anak baik anak usia toddler, usia prasekolah, dan anak usia sekolah, dirawat di Amerika serikat. Sebanyak 3\% sampai dengan $7 \%$ anak usia sekolah yang di rawat di Jerman,serta sebanyak $5 \%$ sampai dengan $10 \%$ anak usia prasekolah yang menjalani hospitalisasi di Kanada. Sedangkan di Indonesia sendiri, angka anak yang sakit dan dirawat dirumah sakit mencapai lebih dari $45 \%$ dari keseluruhan populasi anak di Indonesia, di wilayah Jawa Tengah mencapai 4,74\% [4]).

Hospitalisasi pada anak usia prasekolah ialah kondisi yang mewajibkan anak tinggal di rumah sakit, menempuh pengobatan serta perawatan karena sesuatu alasan yang berencana maupun keadaan darurat. Tinggal dirumah sakit dapat memunculkan tekanan pikiran bagi anak [5]. Hospitalisasi merupakan serangkaian peristiwa traumatik dan penuh kecemasan bagi anak dan orang tuanya, baik itu prosedur yang telah direncan akan sebelumnya maupun situasi darurat yang terjadi akibat trauma [6]. Adapun reaksi anak saat menjalani hospitalisasi antara lain kecemasan dan ketakutan, Bagi anak memasuki rumah sakit adalah seperti memasuki dunia asing, sehingga akibatnya adalah kecemasan dan kekuatan, contohnya ketakutan terhadap lingkungan yang asing atau tidak familiar. Ketika anak berada di rumah sakit, anak menjadi tertekan terhadap lingkungan yang tidak familiar seperti prosedur perawatan kesehatan terutama penggunaan jarum atau nyeri terkait yang dapat terjadi, dan situasi seperti perlengkapan yang terlihat menakutkan (topi bedah,masker,gaun), bau yang tidak familiar, suara bising ataupun suara anak lain yang menangis. Ketika dihospitalisasi, anak mengalami kehilangan control secara signifikan. Dirumah sakit, rutinitas umum anak akan terganggu. Anak kehilangan control terhadap rutinitas perawatan diri dan tugas serta bermain yang biasa merekalakukan dirumah atau sekolah. Misalnya, jika terhubung selang infus, anak mungkin tidak mampu pergi kekamar mandi sendirian[6].

Kecemasan merupakan suatu respon terhadap sesuatu yang dipengaruhi oleh perasaan yang buruk mengenai dirinya. Perasaan cemas yang muncul merupakan ancaman pada individu yang mengalami kepanikan yang berlebihan [7]. Anak yang berada di lingkungan baru sepanjang menjalani hospitalisasi juga merasa takut pada orang asing, selain itu ketidaksukaan anak terhadap lingkungan rumah sakit juga diakibatkan oleh lingkungan rumah sakit yang ramai atau gaduh, suara tangisan anak lain, panas, sarana bermain yang tidak memadai, serta makanan rumah sakit yang mungkin terasa hambar dan tidak lezat [5].

Menurut hasil penelitian yang dilakukan oleh Wahyuni (2016) dari 90 responden didapatkan hasil mayoritas responden berada pada tingkat kecemasan berat, yaitu sebanyak 55 responden $(61,1 \%)$ dan sebagian kecil mengalami tingkat kecemasan ringan yaitu sebanyak 17 responden (38,9\%), Berdasarkan latar belakang permasalahan diatas peneliti tertarik melakukan penelitian menggunakan studi 


\section{Prosiding Seminar Nasional Kesehatan 2021 Lembaga Penelitian dan Pengabdian Masyarakat Universitas Muhammadiyah Pekajangan Pekalongan}

literature review dengan judul "Gambaran Tingkat Kecemasan Hospitalisasi Pada Anak Usia Prasekolah Yang Mengalami Hospitalisasi" .

\section{Metode}

Dalam penelitian ini menggunakan data sekunder. Data yang digunakan tidak langsung terjun secara langsung, melainkan mengambil data dari penelitian terdahulu yang sudah pernah dilaksanakan. Sumber database yang digunakan dalam penelitian ini yaitu Scilit, Garba Garuda dan Google Scholar yang berupa artikel. Artikel yang dianalisa diberi batasan waktu 10 tahun terakhir yaitu 2010-2020, Peneliti membuka web website https://www.scilit.net/statistic-journal , memasukkan kata kunci "Anxiety level AND Hospitalized AND Children AND FAS". Kemudian membuka website https://garuda.ristekbrin.go.id/ ,kata kunci "Tingkat Kecemasan", "FAS", "Hospitalisasi", "Prasekolah". Dan membuka websitehttps://scholar.google.co.id/ kemudian memasukkan kata kunci "Tingkat kecemasan, FAS (face anxiety scale), hospitalisasi, anak usia prasekolah", kemudian diidentifikasi berdasarkan judul dan abstrak serta dipilih berdasarkan criteria inklusi dan didapatkan 5 artikel yang sesuai dengan kriteria inklusi dan eksklusi. Alat ukur yang digunakan untuk menganalisa artikel yaitu instrument JBI critical appraisal checklist for quasi experimental studies.

\section{Hasil dan Pembahasan} Hasil

Hasil analisis data atau literature review berdasarkan variabel penelitian yaitu tingkat kecemasan pada anak yang mengalami hospitalisasi dapat dilihat pada tabel berikut :

Tabel 3.1 Distribusi Frekuensi Karakteristik Responden Berdasarkan Jenis Kelamin

\begin{tabular}{|c|c|c|c|c|c|c|}
\hline \multicolumn{3}{|c|}{ Artikel } & \multicolumn{4}{|c|}{ Jenis kelamin } \\
\hline \multirow[t]{2}{*}{ No } & \multirow[t]{2}{*}{ Penulis } & \multirow[t]{2}{*}{ Tahun } & \multicolumn{2}{|c|}{ Laki-laki } & \multicolumn{2}{|c|}{ Perempuan } \\
\hline & & & $\mathbf{F}$ & $\%$ & $\mathbf{F}$ & $\%$ \\
\hline 1. & Fradianto & 2014 & 14 & 70,0 & 6 & 30,0 \\
\hline 2. & Ramdaniati & 2016 & 28 & 58,3 & 20 & 41,7 \\
\hline 3. & Mulyanti & 2018 & 0 & 0,0 & 0 & 0,0 \\
\hline 4. & Nurmayunita & 2019 & 13 & 65,0 & 7 & 35,0 \\
\hline 5. & Larasaty & 2020 & 16 & 53,3 & 14 & 46,7 \\
\hline \multicolumn{3}{|c|}{$\begin{array}{c}\text { Total masing-masing jenis } \\
\text { kelamin }\end{array}$} & 71 & 60,1 & 47 & 39,9 \\
\hline \multicolumn{3}{|c|}{ Total responden (n) } & \multicolumn{4}{|c|}{118} \\
\hline
\end{tabular}

Berdasarkan hasil literature review dari ke-5 artikel, terdapat 4 artikel yang mencantumkan karakteristik responden berdasarkan jenis kelamin di dapatkan data distribusi frekuensi dan presentase responden berjenis kelamin laki-laki sebanyak 71 anak $(60,1 \%)$ sedangkan responden berjenis kelamin perempuan sebanyak 47 anak $(39,9 \%)$. Maka dapat disimpulkan bahwa responden berjenis kelamin laki-laki lebih banyak dari pada perempuan. 


\section{Prosiding Seminar Nasional Kesehatan 2021 \\ Lembaga Penelitian dan Pengabdian Masyarakat \\ Universitas Muhammadiyah Pekajangan Pekalongan}

Tabel 3.2 Distribusi Frekuensi Karakteristik Responden Berdasarkan Usia

\begin{tabular}{ccccccc}
\hline & Artikel & & \multicolumn{5}{c}{ Usia } \\
\hline \multirow{2}{*}{ No } & Penulis & Tahun & \multicolumn{2}{c}{$\mathbf{3 - 4}$ thn } & \multicolumn{2}{c}{$\mathbf{5 - 6}$ thn } \\
\cline { 3 - 7 } & & F & \% & F & \% \\
\hline 1. & Fradianto & 2014 & 10 & 50,0 & 10 & 50,0 \\
\hline 2. & Ramdaniati & 2016 & 23 & 48,0 & 25 & 52,0 \\
\hline 3. & Mulyanti & 2018 & 16 & 80,0 & 4 & 20,0 \\
\hline 4. & Nurmayunita & 2019 & 5 & 25,0 & 15 & 75,0 \\
\hline 5. & Larasaty & 2020 & 14 & 46,7 & 16 & 53,3 \\
\hline \multicolumn{2}{c}{ Total masing-masing usia } & $\mathbf{6 8}$ & $\mathbf{4 9 , 2}$ & $\mathbf{7 0}$ & $\mathbf{5 0 , 8}$ \\
\hline \multicolumn{7}{c}{ Total responden (n) } \\
\hline
\end{tabular}

Hasil literature review dari ke-5 artikel didapatkan karakteristik responden berdasarkan usia dibedakan menjadi 2 rentang usia, yaitu usia 3-4 tahun dan 5-6 tahun. Jumlah responden yang berusia 3-4 tahun sebanyak 68 anak (49,2 \%) sedangkan responden berusia 5-6 tahun sebanyak 70 anak (50,8\%).

Tabel 3.3 Distribusi Frekuensi Karakteristik Responden Berdasarkan Pengalaman

Dirawat Sebelumnya

\begin{tabular}{|c|c|c|c|c|c|c|}
\hline \multicolumn{3}{|c|}{ Artikel } & \multicolumn{4}{|c|}{ Pengalaman dirawat } \\
\hline \multirow[t]{2}{*}{ No } & \multirow[t]{2}{*}{ Penulis } & \multirow[t]{2}{*}{ Tahun } & \multicolumn{2}{|c|}{ Pernah } & \multicolumn{2}{|c|}{ Belum pernah } \\
\hline & & & $\mathbf{F}$ & $\%$ & $\mathbf{F}$ & $\%$ \\
\hline 1. & Fradianto & 2014 & 12 & 60,0 & 8 & 40,0 \\
\hline 2. & Ramdaniati & 2016 & 17 & 35,4 & 31 & 64,6 \\
\hline 3. & Mulyanti & 2018 & 0 & 0,0 & 0 & 0,0 \\
\hline 4. & Nurmayunita & 2019 & 0 & 0,0 & 0 & 0,0 \\
\hline 5. & Larasaty & 2020 & 8 & 26,7 & 22 & 73,3 \\
\hline \multicolumn{3}{|c|}{$\begin{array}{l}\text { Total masing-masing } \\
\text { pengalaman dirawat }\end{array}$} & 37 & 37,8 & 61 & 62,2 \\
\hline
\end{tabular}

Hasil literature review dari ke-5 artikel terdapat 3 artikel yang memunculkan karakteristik responden berdasarkan pengalaman dirawat sebelumnya, terdapat dua kategori yaitu pernah dirawat dan belum pernah dirawat. Didapatkan hasil pengalaman pernah dirawat sebanyak 37 anak $(37,8 \%)$ dan belum pernah dirawat sebanyak 61 anak $(62,2 \%)$. Maka dapat disimpulkan sebagian besar anak belum pernah dirawat di rumah sakit sebelumnya.

Tabel 3.4 Hasil Analisis Data Artikel Penelitian Tingkat Kecemasan

Pre Intervensi Pada Anak Usia Prasekolah Yang Mengalami Hospitalisasi

\begin{tabular}{|c|c|c|c|c|c|c|c|c|c|c|}
\hline \multicolumn{3}{|c|}{ Artikel } & \multicolumn{8}{|c|}{ Tingkat kecemasan } \\
\hline \multirow[t]{2}{*}{ No } & \multirow[t]{2}{*}{ Penulis } & \multirow[t]{2}{*}{ Tahun } & \multicolumn{2}{|c|}{ Ringan } & \multicolumn{2}{|c|}{ Sedang } & \multicolumn{2}{|c|}{ Berat } & \multicolumn{2}{|c|}{ Panik } \\
\hline & & & $\mathbf{F}$ & $\%$ & $\mathbf{F}$ & $\%$ & $\mathbf{F}$ & $\%$ & $\mathbf{F}$ & $\%$ \\
\hline 1. & Fradianto & 2014 & 0 & 0,0 & 0 & 0,0 & 2 & 10,0 & 18 & 90,0 \\
\hline 2. & Ramdaniati & 2016 & 13 & 27,1 & 21 & 43,8 & 14 & 29,1 & 0 & 0,0 \\
\hline 3. & Mulyanti & 2018 & 12 & 60,0 & 6 & 30,0 & 2 & 10,0 & 0 & 0,0 \\
\hline 4. & Nurmayunita & 2019 & 13 & 65,0 & 7 & 35,0 & 0 & 0,0 & 0 & 0,0 \\
\hline 5. & Larasaty & 2020 & 0 & 0,0 & 11 & 36,7 & 15 & 41,7 & 4 & 13,3 \\
\hline \multicolumn{3}{|c|}{$\begin{array}{l}\text { Total masing-masing } \\
\text { tingkatkecemasan }\end{array}$} & 38 & 27,5 & 45 & 32,6 & 33 & 23,9 & 22 & 16,0 \\
\hline
\end{tabular}




\section{Prosiding Seminar Nasional Kesehatan Lembaga Penelitian dan Pengabdian Masyarakat Universitas Muhammadiyah Pekajangan Pekalongan}

Berdasarkan hasil literature review darike- 5 artikel tingkat kecemasan pada anak usia prasekolah yang mengalami hospitalisasi, 5 artikel terdapat variabel tingkat kecemasan yang terdiri dari kategori kecemasan ringan, sedang, berat dan panik. Didapatkan data responden anak usia prasekolah yang mengalami hospitalisasi mempunyai tingkat kecemasan sedang memiliki hasil terbanyak yaitu sebanyak 45 anak (32,6\%), disusul kecemasan ringan sebanyak 38 anak (27,5\%), kecemasan berat sebanyak 33 anak $(23,9 \%)$, dan panik sebanyak 22 anak $(16,0 \%)$.

\section{Pembahasan}

Berdasarkan analisa data yang dilakukan ke-5 artikel menghasilkan data frekuensi dan presentase dari karakteristik responden yang ditemukan antara lain jenis kelamin, usia, dan pengalaman dirawat sebelumnya. Karakteristik responden yang pertama yaitu jenis kelamin. Jumlah responden berjenis kelamin laki-laki sebanyak 71 anak $(60,1 \%)$ sedangkan responden berjenis kelamin perempuan sebanyak 47 anak (39,9\%). Maka dapat disimpulkan bahwa responden berjenis kelamin laki-laki lebih banyak dari pada perempuan. Menurut Parker \& Wampler (2010), anak laki-laki sering mengalami sakit dibandingkan anak perempuan, dikarenakan anak laki-laki lebih banyak melakukan aktivitas dan kurang teratur dalam pola tidur dan makan karena asyik bermain. Sehingga anak laki-laki sering mengalami sakit dibandingkan anak perempuan.

Karakteristik responden berdasarkan usia pada ke-5 artikel yang direview dikategorikan menjadi 2 rentang usia, yaitu usia 3-4 tahun dan 5-6 tahun. Didapatkan hasil karakteristik responden berdasarkan usia yang memiliki hasil terbanyak yaitu rentang usia 5-6 tahun sebanyak 70 anak (50,8\%), usia 3-4 tahun sebanyak 68 anak $(49,2)$. Anak usia prasekolah ini belum mengerti mana yang kotor dan bersih, terkadang anak sering memungutmakanan yang jatuh di lantai kemudian dimakan kembali, sehingga tanpa pengawasan orang tua menyebabkan anak mudah terserang penyakit seperti diare, batuk maupun flu. Maka dapat disimpulkan semakin muda usia anak akan beresiko mengalami hospitalisasi disebabkan pertahanan sistem imun anak yang masih berkembang sehingga sangat rentan terhadap paparan penyakit [8].

Karakteristik responden dari hasil review ke-3 artikel berikutnya yaitu pengalaman dirawat sebelumnya yang dibagi menjadi dua kategori yaitu pernah dirawat dan belum pernah dirawat. Didapatkan hasil sebagian besar anak belum pernah dirawat di rumah sakit sebelumnya yaitu sebanyak 61 anak (62,2\%). Hal ini sejalan dengan teori Supartini (2012), yang mengatakan bahwa pengalaman anak dirawat di rumah sakit akan menjadikan dasar pengalaman anak untuk mempersepsikan perawatan berikutnya. Ketika anak belum pernah dirawat sebelumnya bisa saja kecemasannya cenderung lebih tinggi karena perawatan di rumah sakit merupakan hal baru, sehingga ketika anak yang sudah memiliki pengalaman sebelumnya cenderung memiliki kecemasan lebih rendah.

Tingkat kecemasan menurut hasil review dari ke-5 artikel dibedakan menjadi 4 tingkatan yaitu kecemasan ringan, sedang, berat dan panik. Hasil analisis data ke-5 artikel anak usia prasekolah yang mengalami tingkat kecemasan ringan sebanyak 38 anak (27,5\%), tingkat kecemasan sedang sebanyak 45 anak (32,6\%), tingkat 


\section{Prosiding Seminar Nasional Kesehatan Lembaga Penelitian dan Pengabdian Masyarakat Universitas Muhammadiyah Pekajangan Pekalongan}

kecemasan berat sebanyak 33 anak (23,9\%), dan panik sebanyak 22 anak (16,0\%). Maka dapat disimpulkan dari ke-5 artikel gambaran tingkat kecemasan anak usia prasekolah yang menjalani hospitalisasi terbanyak mengalami tingkat kecemasan sedang.

Berdasarkan artikel Ramdaniati (2016) didapatkan hampir sebagian responden mengalami kecemasan sedang sebanyak 21 anak (43,8\%), disusul kecemasan berat sebanyak $(29,1 \%)$ dan kecemasan ringan sebanyak 13 anak $(27,1 \%)$ dan tidak ada yang tidak mengalami kecemasan. Berdasarkan artikel Nurmayunita (2019), didapatkan responden mayoritas kecemasan ringan (60\%) yang ditandai dengan kelelahan, kesadaran tinggi, mampu belajar motivasi meningkat dan tingkah laku sesuai situasi. Sedangkan setengahnya sebanyak (35\%) mengalami kecemasan sedang yang ditandai dengan kelelahan meningkat, pernafasan meningkat, kecepatan denyut jantung, ketegangan otot meningkat, bicara cepat dengan volume tinggi, mudah tersinggung, mudah marah, mudah lupa, tidak sabar, mampu untuk belajar namun tidak optimal, lahan persepsi menyempit, kemampuan konsentrasi menurun, dan menangis. Dari keseluruhan 20 responden (100\%) kondisi fisik anak masih memungkinkan beraktifitas, kondisi anak tidak ada yang mengalami pengalaman buruk di rumah sakit, dan disekitar lingkungan dinding ruangan perawatan terdapat tempelan gambar kartun yang membuat suasana tidak menyeramkan bagi anak. Sehingga memicu angka kecemasan ringan yang paling banyak.

Berdasarkan artikel Larasaty (2020) didapatkan data responden kategori terbanyak yaitu kategori cemas berat sebanyak 15 anak $(50,0 \%)$, cemas sedang sebanyak 11 anak $(36,7 \%)$ dan panik sebanyak 4 anak (13,3\%), perilaku kecemasan yang ditunjukkan anak seperti menangis, menjerit, rewel, pucat, menolak didekati, tidak kooperatif saat diajak berinteraksi dan memeluk orang tua. Pada artikel Mulyanti (2018) didapatkan responden mayoritas mengalami kecemasan ringan sebanyak 12 anak (60\%), kecemasan sedang sebanyak 6 anak (30\%) dan kecemasan berat sebanyak 2 anak (10\%). Pada artikel fradianto (2014) didapatkan tingkat kecemasan tertinggi ditunjukkan dengan kategori panik sebanyak 18 anak (90 \%) dan kecemasan berat sebanyak 2 anak (10\%), yang ditandai dengan anak sering menangis, takut kepada tenaga medis dalam melakukan proses atau tindakan kesehatan, marah dan sering murung. Pada penelitian ini didapatkan hasil terbanyak dengan kategori panik, kecemasan ini ditimbulkan akibat perubahan dari lingkungan dan perpisahan yang ditandai dengan anak menangis kuat ketika ditinggalkan oleh orang tuanya, perpisahan pada anak meliputi perpisahan dengan lingkungan yaitu rumah, lingkungan keluarga dan teman bermain. Perpisahan ini menyebabkan krisis situsional pada anak.

Kecemasan yang dialami anak selama hospitalisasi tidak dapat dibiarkan, karena dapat menimbulkan dampak buruk diantaranya proses penyembuhan anak dapat terhambat, menurunnya semangat untuk sembuh dan tidak kooperatifnya anak terhadap tindakan perawatan [9]. Dalam mengatasi kecemasan ini salah satunya dapat dilakukan intervensi yaitu terapi bermain, terapi bermain merupakan terapi pada anak yang menjalani hospitalisasi. Permainan anak akan membuat anak terlepas dari ketegangan dan stress yang dialaminya karena dengan melakukan permainan anak dapat mengalihkan rasa sakitnya pada permainannya dan relaksasi melalui 


\section{Prosiding Seminar Nasional Kesehatan 2021 Lembaga Penelitian dan Pengabdian Masyarakat Universitas Muhammadiyah Pekajangan Pekalongan}

kesenangannya melakukan permainan [10]. Salah satu terapi bermain yang sesuai adalah terapi bermain dengan kelompok jenis usia, dimana salah satu kelompok usia adalah pada usia prasekolah, alat permainan yang tepat pada usia prasekolah yang mempunyai manfaat selain untuk kebutuhan bermainnya juga dapat menggembangkan kemampuan motoriknya [10]. Sehingga, perawat di ruang anak dapat memberi asuhan keperawatan dengan tetap memperhatikan aspek psikologi dan tumbuh kembang anak denga nmemberikan kebutuhan bermain bagi anak saat dirawat untuk menurunkan tingkat kecemasan pada anak. Serta perawat dapat memberikan pengarahan dan motivasi kepada orang tua, ketika anak dilakukan tindakan keperawatan orang tua bisa selalu mendampingi anak saat menjalani proses perawatan selama di rumahsakit, sehingga dapat meminimalkan kecemasan pada anak saat mengalami rawat inap di rumah sakit.

\section{Kesimpulan}

Karakteristik anak usia prasekolah yang mengalami hospitalisasi didapatkan dari ke-5 artikel didapatkan hasil laki-laki sebanyak 71 (60,1\%), perempuan 47 (39,9\%). Usia 3-4 tahun sebanyak 68 (49,2\%), usia 5-6 tahun sebanyak $70(50,8 \%)$. Anak yang belum pernah dirawat di rumah saki tsebelumnya yaitu sebanyak $61(62,2 \%)$ dan anak yang pernah dirawat di rumah sakit sebelumnya yaitu sebanyak 37 (37,8\%).

Tingkat kecemasan anak usia prasekolah yang mengalami hospitalisasi didapatkan hasil terbanyak yaitu tingkat kecemasan sedang sebanyak 45 anak (32,6\%), kecemasan ringan 38 anak (27,5\%), kecemasan berat sebanyak 33 anak (23,9\%), dan panik sebanyak 22 anak (16,0\%).

\section{Referensi}

[1] M. Ns. Arif Rohman Mansur, TUMBUH KEMBANG ANAK USIA PRASEKOLAH, 2019.

[2] D. Pujiana, "HUBUNGAN ANTARA KECEMASAN DENGAN POLA TIDUR PADA ANAK YANG MENGALAMI HOSPITALISASI DI RUANG ANAK RUMAH SAKIT MUHAMMADIYAH PALEMBANG 2017," vol. 6, no. 1, p. 1, Juni 2018.

[3] W. Anggika A, "TINGKAT KECEMASAN PADA ANAK PRASEKOLAH YANG MENGALAMI HOSPITALISASI BERHUBUNGAN DENGAN PERUBAHAN POLA TIDUR DI RSUD KARANGANYAR," vol. XIV, no. 1, p. 1, 2 Agustus 2016.

[4] H. STATISTICS, PROFIL KESEHATAN INDONESIA TAHUN 2018, Jakarta, 2019.

[5] N. P. Mendri, Asuhan Keperawatan Pada Anak Sakit Bayi Resiko Tinggi, Yogyakarta, 2017.

[6] T. C. S. Kyle, Buku Ajar Keperawatan Pediatri Edisi 2, vol. 2, Jakarta, 2019.

[7] T. Lestari, Teori Untuk Kajian Pustaka Penelitian Kesehatan, Yogyakarta: Nuha Medika, 2015.

[8] P. A. A. Y. Y. Padila, "Terapi storytelling dan menonton animasi kartun terhadap ansietas," Journal of telenursing (JOTING), 2019. 


\section{Prosiding Seminar Nasional Kesehatan $\mathbf{2 0 2 1}$ Lembaga Penelitian dan Pengabdian Masyarakat Universitas Muhammadiyah Pekajangan Pekalongan}

[9] S. Tarbiyah, "Gambaran Tingkat Kecemasan pada anak usia prasekolah saat mengalami hospitalisasi di RS PMi Kota Bogor," 2018.

[10] Fradianto, ikbal,"Pengaruh terapi bermain lilin terhadap penurunan tingkat kecemasan pada anak usia prasekolah yang mengalai hospitalisasi di Rsud DR.Soedarso Pontianak," Jurnal PRONERS, 2014

[11] Legi, J. R., Sulaiman, S,. Purwati, N. H.,"Pengaruh Storytelling dan GuidedImagery Terhadap Tingkat Perubahan Kecemasan Anak Usia Prasekolah yang Dilakukan Tindakan Invasif".Jurnal of Telenursing (JOTING), 2019

[12] Larasaty,ferra D. ,"Pengaruh terapi bermain storytelling dengan media hand puppet terhadap kecemasan hospitalisasi anak usia pra sekolah di RSUD Dr. R. Goeteng Taroenadibrata Purbalingga". Jurnal keperawatan muhammadiyah September 2020.2020

[13] Ramdaniati,Sri . ,"Comparison study of art therapy and play therapy in reducting anxiety on pre-school children who experience hospitalization". Open journal of nursing, 2016

[14] Mulyanti,S. ,"Pengaruh terapi bermain terhadap tingkat kecemasan anak usia prasekolah akibat hospitalisasi di Rsud Dr. Soekardjo Kota Tasikmalaya". Jurnal BIMTAS, 2018

[15] Alini. ,Pengaruh terapi bermain plastisin (playdought) terhadap tingkat kecemasan anak usia prasekolah (3-6 tahun) yang mengalami hospitalisasi di ruang perawatan anak RSUD Bangkinang" , 2017

[16] Apriany,Dyna. ,"Perbedaan efektifitas terapi mewarnai dan bermain puzzle terhadap kecemasan anak prasekolah yang mengalami hospitalisasi di rumah sakit umum kota cimahi",2018.

[17] Rini, Mustika D. ,"Hubungan Penerapan Atraumatic Care dengan Kecemasan Anak Prasekolah Saat Proses Hospitalisasi di RSU dr. H. Koesnadi Kabupaten Bondowoso", 2013.

[18] Moola, S, dkk. , "Checklist for analytical cross sectional studies. Joanna brings institute reviewer's" . , 2017

[19] Saputro, H \& Fazrin, I. , "Anak Sakit Wajib Bermain Di Rumah Sakit : Penerapan Terapi Bermain Saat Anak Sakit, Manfaat Dan Pelaksanaannya". Ponorogo,indonesia : Forum IImiah Kesehatan (FORIKES),2017

[20] Fatmawati,L. ,"Pengaruh audiovisual menonton film kartun terhadap tingkat kecemasan saat prosedur injeksi pada anak prasekolah" Jurnal IImiah Kesehatan (Journal Of Health Science). vol 12, 2019

[21] Poernomo, Dewi ika. ,"Kecemasan anak usia toddler yang rawat inap dilihat dari gejala umum kecemasan masa kecil". Jurnal penelitian keperawatan Vol 2. ,Agustus 2016.

[22] Y. Supartini, Buku Ajar Konsep Dasar Keperawatan Anak, Jakarta: EGC, 2012 